\title{
THE RELATIONSHIP BETWEEN CEO COMPENSATION AND COMPANY PERFORMANCE IN A SOUTH AFRICAN CONTEXT
}

\author{
Samuel Bradley* \\ Rhodes University \\ samwisebradley@gmail.com
}

Received: January 2013

Accepted: October 2013

\begin{abstract}
The goal of this research was to determine, in a South African context, whether there is any correlation between chief executive officer compensation and the performance of the company. For the purposes of the research, the compensation of chief executive officers was broken down into three components: salary, bonus and 'other' remuneration, while company performance was measured on return on equity, return on assets and earnings per share figures. Data in respect of the forty largest listed companies in South Africa were collected over a period of five years. The results of this study indicate that there is no linear relationship between chief executive officer compensation and company performance variables. The econometric models did, however, show correlations between certain variables, taking into account the other predictor variables in the model. Evidence of correlations between age, experience and compensation was also found.
\end{abstract}

Keywords

Chief executive officer, Company performance, Compensation, Remuneration, Return on equity, Earnings per share, Return on assets, C $\subset 0$ age, C $C O$ experience

*Mr Samuel Bradley is a master's student in Accounting at Rhodes University, South Africa. 


\section{INTRODUCTION}

Executive compensation has been in the limelight recently and often for the wrong reasons (Ozkan, 2011). The financial crisis of 2008 has led to many national recessions, as well as retrenchments and other cost-cutting measures at companies. This situation has increased the awareness of the general public of the pay-cheques of the rich and powerful (Bognanno, 2010), with more and more fingers being pointed at these 'outrageously high salaries for executives' (Sharma \& Smith, 2001:7). South Africans were reminded of this in July 2011 when a petroleum workers' strike caused fuel shortages. The strike took place to 'protest against massive pay hikes of the executives at Sasol' (Khuzwayo \& Matomela, 2011:1).

The amount of legislation dealing with executive compensation has also increased (Morrissey, 2009). In America the Troubled Asset Relief Program instituted legislation in an attempt to halt the increase in executive compensation, with measures such as 'say on pay' resolutions (nonbinding advisory votes from shareholders) and increased disclosure requirements being instituted (Kim, 2010). Companies in South Africa are regulated by the King Code of Governance Principles and the King Report on Governance (Institute of Directors Southern Africa, 2009) ('King III'), as well as the Companies Act 2008 (South Africa Government Online, 2009) ('Company Act 2008').

Much criticism has been levelled at companies (and their remuneration committees in particular) for the increases in executive compensation in the face of disappointing financial results (Grunditz \& Lindqvist, 2003). Ozkan (2011) stated that it is widely felt that the link between executive compensation and company performance is not strong enough, meaning that directors receive their compensation regardless of the results of the company. As stated by former American Securities Exchange Commission chairman Mr Andrew Levitt, the 'single greatest impediment to the restoration of confidence in corporate America is continuing instances of extravagant non-performance-based compensation' (Levitt, 2004:1).

It is in this current economic climate that the present research is relevant. Research on chief executive officer (CEO) pay has grown even faster than actual CEO pay (Murphy, 1999), and it is to this body of knowledge that this research attempts to add. South African disclosure requirements have increased due to the release of the King Code of Governance Principles and the King Report on Governance in 2009 (Temkin, 2009), and consequently the data necessary for this research should be readily available from companies' annual reports. International studies have been carried out on the same topic, with most studies finding no link between the two variables. Most of the research has been done in the United States of America (USA) and the United Kingdom (UK). Studies in the USA that have focused on the relationship between compensation and performance include Lambert and Larcker (1987); Jensen and Murphy (1990); Murphy (1999); Baber, Kang and Kumar (1999); and Ofek and Yermack (2000).

In the United Kingdom, Conyon, Gregg and Machin (1995); Gregg, Jewell and Tonks (2005); and Girma, Thompson and Wright (2007) found weak relationships between compensation and performance, although 0zkan (2011:260) found 'a positive and significant relationship' between CEO compensation and firm performance. A study in Sweden by Grunditz and Lindqvist (2003) showed no link, while a Danish study by Eriksson and Lausten (2000) showed a weak link between executive compensation and company performance. A study in Australia and Canada by Sharma and Smith (2001:6) failed to find a 'robust relationship' between company performance and base salary growth. 
Studies on executive compensation have also been performed in South Africa. Oberholzer and Theunissen (2012) found that C\&O compensation in South Africa is excessive, probably due to the use of the Linear Regression Analysis method to set $C \varepsilon 0$ compensation benchmarks. Theunissen (2010) found that the variable portion of $C \& 0$ compensation was positively linked to company performance, while Dommisse (2011) also found that remuneration was linked to company performance. In addition, a study on remuneration was performed which showed that $41 \%$ of CEO salaries tested were overpaid relative to their peers (Lund, 2012). However, a current gap in the available research exists, as none of these studies examine the effect of company performance on CEO compensation as well as the effect of C $\subset 0$ compensation on company performance.

Therefore the goal of the research is to determine, in a South African context, whether there is a correlation between $C \& 0$ compensation and the performance of the company. If such a correlation does exist, the secondary goal of the research is to analyse the effect that $C \& 0$ compensation has on the performance of a company. The specific aims of the research are as follows:

- to determine whether there is a correlation between $C \& 0$ compensation and company performance;

- to determine whether the relationship between $C \& 0$ compensation and company performance is influenced by the industry in which the company operates;

- to determine whether variable compensation (for example bonuses) affects the performance of the company; and

- to determine whether $C \& 0$ compensation is affected by variables such as the age and experience of the CEO.

The research used the forty largest publicly listed companies on the Johannesburg Stock Exchange (JSE), measured by market capitalisation on 18 March 2010. The reason for selecting these companies as the sample is that because they are listed on the JSE, they are required to follow JSE listing requirements, and will therefore disclose the data that are needed for the study. Despite the fact that only the forty largest companies have been included in the sample, these companies have a combined market capitalisation of $66.70 \%$ of the total JSE capitalisation. It is therefore concluded that this is a large enough proportion of the total capitalisation to be sufficient for the research. The fact that all the companies selected are large companies would therefore address the problem of company size as a threat to the validity of the research.

\section{BACKGROUND}

\subsection{Conceptual scope}

The goal of the research is to determine whether there is a correlation between $C \varepsilon 0$ compensation and the performance of the company. The agency relationship explains the link between these variables: it is because the agency problem exists that directors will not always do their utmost for the sake of the company, and therefore need to be motivated through incentive-based compensation to perform. To mitigate the risks posed by the agency relationship, $C \& O$ compensation is used as a means to regulate and motivate the performances of the directors (Shaw \& Zhang, 2010). This research is seeking to evaluate the correlation between director's compensation and their performance, which will demonstrate whether $c \varepsilon 0$ 
compensation can be used as an effective method for countering the agency problem, and thereby controlling director performance. The variables used to measure C£O compensation and company performance (and to determine whether the two are correlated) are documented below.

\subsection{CEO compensation variables}

'C\&0 compensation is defined as the sum of base pay, bonuses, stock grants, stock options, other forms of compensation and benefits' (Bognanno, 2010:2). Based on past research, the components of $C \& O$ compensation to be analysed in the present research were split into four categories, consisting of base salary, bonus, benefits and long-term incentives. Murphy (1999) separates executive compensation into these same four components (salary, bonus, other payments and long-term payments) in his study on executive compensation.

Any fixed remuneration received during the year was included in the subtotal reflecting the salary. Director's fees, cash remuneration and any form of guaranteed compensation were also included. Short-term bonuses were deemed to include any unguaranteed forms of compensation. The salary was analysed separately from the bonus, as the bonus element of compensation is more likely to be dependent on performance than the salary element. All bonuses due in less than twelve months were categorised as 'short term,' and included as part of this component of remuneration. As stated by Levitt (2004), many companies try to disguise the actual compensation paid to executives by including fringe benefits (such as corporate jets) in their compensation. This study aims to include these benefits in the research. 'Other' remuneration includes all non-cash rewards, such as insurance payments, club memberships, retirement contributions and payments, contributions to defined contribution plans, pension contributions and any other benefits paid by the company on behalf of its $\subset \varepsilon 0$. Currently there are various different long-term options or share schemes used by companies to reward their executive team. Calculating the value of options and shares awarded during a year, and putting the data into a standard format, is beyond the scope of this research. Most other research on this topic has excluded the value of long-term options from the data set. By excluding it from the present research, the findings are more readily comparable to other research. A study by Tower Perrin showed that with regard to CEO remuneration in the USA, stock options had fallen from $38 \%$ of total CE0 remuneration in 2004 to $23 \%$ in 2008, making them less relevant to the study of CEO remuneration as time progressed (Farmer, 2008).

\subsection{Company performance variables}

Company performance is measured either by using stock market indicators or by using accounting earnings measures (Eriksson \& Lausten, 2000). In order to ensure that this study is comparable to similar studies, the variables chosen to measure company performance are widely known and commonly used. The data for the forty companies selected on the JSE also needed to be readily available for the measures chosen. Only accounting measures were therefore used, due to the fact that the data are 'verifiable and widely understood' (Murphy, 1999:2490). Murphy also stated that the 'the primary determinant of executive compensation is accounting profits' (1999:2490).

The following three measures were used:

Firstly, return on equity (ROE), which is a widely used performance measure both in evaluating management performance and in determining executive compensation (Pandya \& Rao, 1998), 
and was described as a metric that is 'most meaningful when evaluating publicly owned companies' (Siciliano, 2003:111). ROE is defined as net income (i.e. income distributable to shareholders) divided by shareholder equity (Pandya \& Rao, 1998). Hagel, Brown and Davison (2010) suggest that it is logical that ROE has remained the most enduring and popular performance measure, as its focus is on shareholder returns, which is of primary importance to the investor. ROE is also a measure of how well a company uses debt in its capital structure in order to maximise shareholder returns. ROE has been criticised due to the fact that it is an accounting figure and therefore could be manipulated by management to appear better than it actually is (Rosen, 1992). Due to the fact that the ROE figure for a company could be manipulated by unscrupulous managers, and in order to make this study more complete, two more variables were introduced. Using additional measures of performance also has the advantage of increasing the possibility of identifying a correlation between $C \& 0$ compensation and company performance.

Secondly, earnings per share (EPS), which is a commonly used performance measure, and is also very commonly used as a bonus base (Mäkeläinen, 1998). It has been described as a 'central performance indicator for shareholders' by Otley (2002:10) and was described by Bunting (2009:19/1) as a 'fundamentally important performance indicator.' This ratio is calculated by dividing the earnings (or profits) by the number of shares in issue (Bunting, 2009).

EPS also has the advantage of being widely recognised and accepted, which was shown by the fact that it was used as a performance measure in most of the previous research papers used for comparison. Kozan and Boulanger (2004) pointed out that accounting measures (such as EPS) have many advantages: they are affected by both revenues and expenses, they force managers to focus on generating profits and they are easily measurable.

Thirdly, return on assets (ROA) measures the profits that a company generates with the assets that it controls. It is a good measure of the performance of management of the company, as it analyses how well assets are being used by management to generate accounting returns. Hagel et al. (2010) pointed out that ROA is a better measure of financial performance than income statement performance measures, as it explicitly takes into account the assets that are used to generate returns. There are a few variances of this formula, but it is suggested that the most commonly used formula is the 'Return on Average Assets' formula, which is: ROA = profit after tax/average assets. Unlike ROE, the capital structure of debt and equity chosen by management does not affect the ROA measurement.

\section{RESEARCH DESIGN AND METHOD}

\subsection{Research design}

It was decided that it would be beneficial to group the companies into sectors or industries. This allowed for meaningful comparisons to be made within the sectors, and also ensured that the sample is well diversified and that each sector is represented in the research.

Various factors were considered when allocating companies to the three sectors which were chosen for the purposes of this research. The JSE formally recognises thirty sectors, which is too large to be practical for the purposes of this research. Murphy recognises four groups of industry, namely mining and manufacturing, financial services, utilities and other industries 
(Murphy, 1999). These sectors were slightly adapted for this research paper into three sectors, and are as follows:

- Mining - includes mining for any mineral, precious stone or raw material, or exploration for such materials;

- Financial services - includes banking, logistics, insurance and health care;

- Industrial - includes agriculture, building construction, processing and manufacturing of goods, pharmaceuticals, tobacco, jewellery, property, telecommunications, media, industrial goods, food and beverages, oil and gas, retail and personal and household goods.

The sample chosen has the following number of companies in the following sectors: Mining 12, Financial services 12 and Industrials 16 .

\subsubsection{Statistical method}

The company performance variables for a period of six years from 2005 to 2010 (inclusive) were used for the purposes of the study. Multivariate analysis was used to identify the independent variables that influence the dependent variable, with the $C \varepsilon 0$ compensation variables initially assumed to be the independent variables. Data regarding C $\subset 0$ compensation was obtained for the five years from 2006 to 2010 (inclusive). The company performance variables are therefore assumed to be the dependent variables. The dependent variable has been included for an extra year in order to test whether there is a 'lag-effect' (i.e. the independent variables only change due to the current state of the dependent variable in the following year). The data has only been collected for this period due to the availability of data. Disclosure of sensitive information such as CEO compensation has improved during recent years in South Africa (van Zyl, Smit \& Nel, 2010), and this data was not made available prior to 2006 by many of the companies selected.

There are reasons to believe that independent variables will be better correlated to dependent variables in the following year than in the current year (Doucouliagos, Haman \& Askary, 2007). Boschen and Smith (1995) stated that remuneration contracts often contain an element of deferred compensation, meaning that performance by a $\subset \varepsilon 0$ in a current period will result in a change in remuneration only in a future period. Companies themselves seem to recognise the existence of a lag between remuneration and performance: many of the remuneration reports within the annual reports emphasised the aim to use compensation incentives to reward longterm and sustainable growth rather than short-term gains. Another possible reason for a lag between performance and remuneration could be due to the recent increased use of compensation consultants (Doucouliagos et al., 2007).

\subsubsection{Limitations of the research design}

Certain limitations apply to the present research. The performance of a company can be influenced by all the employees and management of a company, not just the CEO. However, because the $C \& 0$ is responsible for providing the vision and the business model for the company (as well as having the most easily accessible compensation figures), this study is focused solely on the $C £ 0$. Another reason for this is that prior studies have found that 'pay performance association is stronger and more direct for CEO remuneration than it is for total directors' remuneration' (Doucouliagos et al., 2007:1363).

The gathering of the source data has been done with as little bias as possible. Figures measuring company performance have been drawn from an independent and trustworthy source, namely 
the Profile's Stock Exchange Handbook (Profile Media, 2010). A small proportion of the data could not be obtained from this source and was calculated using figures from the companies' annual reports.

\subsubsection{Design of the models}

This research details the collection of the data as well as the design of the models used to analyse the data. The accuracy of the data is important because in order for the findings to be valid, the data needs to be accurate, valid and reliable. The data is used to achieve the goal of the research, which is to determine whether a correlation between company performance exists in a South African context. Once the models have been formulated possible errors are tested for in order to assess the reliability of the data. Descriptive statistics that summarise the data for each year from 2006 until 2010 are then presented.

For each of the companies listed, the (E0's name, age (on 1 January 2011) and length of service (as at 1 January 2011) were obtained.

The following data was collected for the years 2006, 2007, 2008, 2009 and 2010:

- guaranteed compensation - cash salary and directors fees;

- short-term performance bonuses; and

- non-cash rewards, insurance, club memberships, other benefits and retirement contributions.

The following data were collected for the years 2005, 2006, 2007, 2008, 2009 and 2010:

- ROE (\%), ROA (\%) and EPS (South African cents).

In a few cases, despite extra research and correspondence with the company, some data has remained unattainable. Where this has occurred, the statistical analysis was run on the remaining population. It is submitted that the quantity of missing data was small enough not to compromise the results.

\subsection{Research method}

While it is hypothesised that $C \varepsilon 0$ compensation affects company performance, there is still the possibility that it is company performance that affects $C \& O$ compensation. It was therefore necessary to apply different econometric models in order to capture various possible relationships between C\&O compensation and company performance (Grunditz \& Lindquist, 2003).

Various models have been created in order to test for correlations within different business sectors. First the effect of $C E O$ compensation on company performance is shown by analysing each of the $C \varepsilon O$ variables separately in order to determine their level of correlation to company performance. Then the same method is used to test company performance for correlation to CEO compensation.

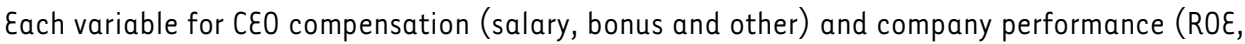
ROA and EPS) is analysed as the dependent variable. The coefficient of determination $\left(R^{2}\right)$ measures the proportion of the variation in the dependent variable, which can be explained by the variation in the independent variables (Grunditz \& Lindqvist, 2003). The coefficient of determination ranges between zero and one and has been referred to as 'a descriptive measure 
of the goodness of fit' (Grunditz \& Lindqvist, 2003:36), with a higher figure showing a stronger correlation than a lower figure. This can be seen in the six econometric models presented.

A number of econometric models were used to analyse the data in order to determine the variables that may affect the remuneration of the $\subset \mathcal{C} 0$ and the company performance. For each of the six econometric models presented the Financial Services Sector dummy variable has been omitted. This has been done to avoid the dummy variable trap (Hirschberg \& Lye, 2001). This is an error that is created when a model contains exact collinearity, meaning that the matrix of the independent variables is singular.

\subsubsection{Company performance or other variables affecting CEO compensation}

Econometric Model 1: Salary as dependent variable

$$
Y_{i}=\beta_{0}+\beta_{1} X_{1 i}+\beta_{2} X_{2 i}+\beta_{3} X_{3 i}+\beta_{4} X_{4 i}+\beta_{5} X_{5 i}+\beta_{6} X_{6 i}+\beta_{7} X_{7 i}+\delta_{1} D_{1 i}+\delta_{2} D_{2 i}+\varepsilon_{i}
$$

for $i=1,2, \ldots . ., n$, where $Y_{i}=$ Salary, $X_{1 i}=$ Age, $X_{2 i}=$ Service, $X_{3 i}=$ Bonus, $X_{4 i}=$ Other, $X_{5 i}=$ ROE, $X_{6 i}=$ ROA, $X_{7 i}=\varepsilon P S, D_{1 i}=$ Mining, $D_{2 i}=$ Industrial and $\varepsilon_{i}$ are independent, identically distributed $N\left(0, \sigma^{2}\right)$.

Econometric Model 2: Bonus as dependent variable

$$
Y_{i}=\beta_{0}+\beta_{1} X_{1 i}+\beta_{2} X_{2 i}+\beta_{3} X_{3 i}+\beta_{4} X_{4 i}+\beta_{5} X_{5 i}+\beta_{6} X_{6 i}+\beta_{7} X_{7 i}+\delta_{1} D_{1 i}+\delta_{2} D_{2 i}+\varepsilon_{i}
$$

for $i=1,2, \ldots . ., n$, where $Y_{i}=$ Bonus, $X_{1 i}=$ Age, $X_{2 i}=$ Service, $X_{3 i}=$ Salary, $X_{4 i}=$ Other, $X_{5 i}=$ R0E, $X_{6 i}=$ ROA, $X_{7 i}=\varepsilon P S, D_{1 i}=$ Mining, $D_{2 i}=$ Industrial and $\varepsilon_{i}$ are independent, identically distributed $N\left(0, \sigma^{2}\right)$.

Econometric Model 3: 'Other' as dependent variable

$$
Y_{i}=\beta_{0}+\beta_{1} X_{1 i}+\beta_{2} X_{2 i}+\beta_{3} X_{3 i}+\beta_{4} X_{4 i}+\beta_{5} X_{5 i}+\beta_{6} X_{6 i}+\beta_{7} X_{7 i}+\delta_{1} D_{1 i}+\delta_{2} D_{2 i}+\varepsilon_{i}
$$

for $i=1,2, \ldots . ., n$, where $Y_{i}=$ Other, $X_{1 i}=$ Age, $X_{2 i}=$ Service, $X_{3 i}=$ Salary, $X_{4 i}=$ Bonus, $X_{5 i}=$ R0E, $X_{6 i}=$ ROA, $X_{7 i}=\varepsilon P S, D_{1 i}=$ Mining, $D_{2 i}=$ Industrial and $\varepsilon_{i}$ are independent, identically distributed $N\left(0, \sigma^{2}\right)$.

\subsubsection{CEO compensation or any other variables affecting company performance}

Econometric Model 4: ROE as dependent variable

$$
Y_{i}=\beta_{0}+\beta_{1} X_{1 i}+\beta_{2} X_{2 i}+\beta_{3} X_{3 i}+\beta_{4} X_{4 i}+\beta_{5} X_{5 i}+\delta_{1} D_{1 i}+\delta_{2} D_{2 i}+\varepsilon_{i}
$$

for $i=1,2, \ldots . ., n$, where $Y_{i}=$ ROE, $X_{1 i}=$ Age, $X_{2 i}=$ Service, $X_{3 i}=$ Salary, $X_{4 i}=0$ ther, $X_{5 i}=$ Bonus, $D_{1 i}=$ Mining, $D_{2 i}=$ Industrial and $\varepsilon_{i}$ are independent, identically distributed $N\left(0, \sigma^{2}\right)$. 
Econometric Model 5: ROA as dependent variable

$$
Y_{i}=\beta_{0}+\beta_{1} X_{1 i}+\beta_{2} X_{2 i}+\beta_{3} X_{3 i}+\beta_{4} X_{4 i}+\beta_{5} X_{5 i}+\delta_{1} D_{1 i}+\delta_{2} D_{2 i}+\varepsilon_{i}
$$

for $i=1,2, \ldots . ., n$, where $Y_{i}=$ ROA, $X_{1 i}=$ Age, $X_{2 i}=$ Service, $X_{3 i}=$ Salary, $X_{4 i}=$ Other, $X_{5 i}=$ Bonus, $D_{1 i}=$ Mining, $D_{2 i}=$ Industrial and $\varepsilon_{i}$ are independent, identically distributed $N\left(0, \sigma^{2}\right)$.

Econometric Model 6: EPS as dependent variable

$$
Y_{i}=\beta_{0}+\beta_{1} X_{1 i}+\beta_{2} X_{2 i}+\beta_{3} X_{3 i}+\beta_{4} X_{4 i}+\beta_{5} X_{5 i}+\delta_{1} D_{1 i}+\delta_{2} D_{2 i}+\varepsilon_{i}
$$

for $i=1,2, \ldots . ., n$, where $Y_{i}=$ EPS, $X_{1 i}=$ Age, $X_{2 i}=$ Service, $X_{3 i}=$ Salary, $X_{4 i}=$ Other, $X_{5 i}=$ Bonus, $D_{1 i}=$ Mining, $D_{2 i}=$ Industrial and $\varepsilon_{i}$ are independent, identically distributed $N\left(0, \sigma^{2}\right)$.

\subsection{Possible econometric specification errors}

If the underlying assumptions of the linear regression model are incorrect, there is a possibility of specification errors. The assumptions of the disturbance term are normality and homogeneity of the variances and that the disturbances are pair-wise uncorrelated. The assumptions of the explanatory variables (regressors) are that they are non-stochastic and linearly independent.

\subsubsection{Autocorrelation}

The Durbin-Watson $d$ statistic was used to test for autocorrelation of the disturbances. Tables giving the upper and lower bounds $\left(d_{L}\right.$ and $\left.d_{U}\right)$ for $d$ were used to test for zero autocorrelation against the alternative positive first-order autocorrelation if the value of $d$ was less than 2 . If the value of $d$ was greater than 2 the value of $4-d$ was compared with the tabulated upper and lower bounds to test for zero autocorrelation against the alternative negative first-order autocorrelation.

\subsubsection{Heteroscedasticity}

Detection of heteroscedasticity of the disturbance variance was examined by means of residual plots. The Breusch-Pagan Godfrey test was also used to test for homoscedasticity of the disturbances against the alternative heteroscedasticity. The hypothesis of homoscedasticity is rejected for large values of the test statistic, compared to the tabulated chi-squaredistribution critical values.

\subsubsection{Normality of the disturbances}

The Kolmogorov-Smirnov test on the residuals was used to test for normality of the disturbances.

\subsubsection{Multicollinearity}

The presence of multicollinearity was detected by examining the correlation coefficient matrix of the regressors. The hypothesis of no multicollinearity is rejected for large values of the sample correlation coefficient. 


\section{THE \&FFECT OF CEO COMPENSATION ON COMPANY PERFORMANCE}

The following analysis shows the effect on company performance when C $\mathcal{0} 0$ compensation figures are changed. For each variable of C $\subset 0$ compensation a table of descriptive statistics is presented as well as a graph showing the average amounts of that variable for each of the three sectors (the bars in the graph denote standard errors). An econometric model with the various C $£ 0$ compensation variables as the dependent variables is then presented, along with the results and finally the findings of the diagnostic tests of the assumptions of the linear model.

\subsection{Salary as dependent variable}

\section{TABLE 1: Descriptive statistics for salary}

All figures except for $n$ are given in thousands, and refer to South African Rands

\begin{tabular}{|c|c|c|c|c|c|c|c|}
\hline Sector & year & $n$ & Mean & Std. Dev. & Std. Err. & $\begin{array}{c}\text { lower } \\
95 \%\end{array}$ & $\begin{array}{c}\text { upper } \\
95 \%\end{array}$ \\
\hline & 2006 & 36 & 4551.73 & 3304.28 & 550.71 & 3433.72 & 5669.7 \\
\hline & 2007 & 37 & 5659.76 & 4414.39 & 725.72 & 4187.93 & 7131.6 \\
\hline & 2008 & 39 & 5737.63 & 4365.94 & 699.11 & 4322.35 & 7152.9 \\
\hline & 2009 & 39 & 5923.05 & 4198.28 & 672.26 & 4562.12 & 7284.0 \\
\hline & 2010 & 39 & 6714.44 & 4719.41 & 755.71 & 5184.58 & 8244.3 \\
\hline Financial & 2006 & 11 & 3760.63 & 2036.97 & 614.17 & 2392.17 & 5129.1 \\
\hline Financial & 2007 & 12 & 4224.65 & 2300.90 & 664.21 & 2762.73 & 5686.6 \\
\hline Financial & 2008 & 13 & 4052.10 & 2519.24 & 698.71 & 2529.74 & 5574.5 \\
\hline Financial & 2009 & 13 & 4486.75 & 2596.16 & 720.05 & 2917.90 & 6055.6 \\
\hline Financial & 2010 & 13 & 4655.78 & 2466.92 & 684.20 & 3165.04 & 6146.5 \\
\hline Industry & 2006 & 12 & 4554.22 & 4063.36 & 1172.99 & 1972.48 & 7136.0 \\
\hline Mining & 2007 & 12 & 6001.01 & 5321.15 & 1536.09 & 2620.11 & 9381.9 \\
\hline Mining & 2008 & 12 & 6223.65 & 4769.75 & 1376.91 & 3193.09 & 9254.2 \\
\hline Mining & 2009 & 12 & 6923.07 & 4154.87 & 1199.41 & 4283.19 & 9563.0 \\
\hline Mining & 2010 & 12 & 7084.75 & 3794.10 & 1095.26 & 4674.09 & 9495.4 \\
\hline Industrial & 2006 & 13 & 5218.82 & 3492.33 & 968.60 & 3108.43 & 7329.2 \\
\hline Industrial & 2007 & 13 & 6669.48 & 4936.79 & 1369.22 & 3686.21 & 9652.7 \\
\hline Industrial & 2008 & 14 & 6886.17 & 5111.71 & 1366.16 & 3934.76 & 9837.6 \\
\hline Industrial & 2009 & 14 & 6399.58 & 5240.37 & 1400.55 & 3373.88 & 9425.3 \\
\hline Industrial & 2010 & 14 & 8308.64 & 6340.77 & 1694.64 & 4647.59 & 11969.7 \\
\hline
\end{tabular}

Source: Author's analysis 
TABLE 2: Econometric Model 1 showing salary as the dependent variable with lagged ROE, ROA and EPS

\begin{tabular}{|c|c|c|c|c|}
\hline \multirow[t]{2}{*}{$n=189$} & \multicolumn{3}{|c|}{$\begin{array}{l}\text { Regression Summary for Dependent Variable: Salary } \\
R=0.680, R^{2}=0.462 \text {, Adjusted } R^{2}=0.435 \\
F(9,179)=17.01, p<.0001\end{array}$} & \multirow[b]{2}{*}{$p$-value } \\
\hline & B & Std.Err.ofb & $t(179)$ & \\
\hline Intercept & 4566.41 & 2893.47 & 1.58 & 0.1163 \\
\hline Age & -71.33 & 59.70 & -1.19 & 0.2337 \\
\hline Service & 177.67 & 53.86 & 3.30 & 0.0012 \\
\hline Bonus & 0.17 & 0.04 & 4.33 & $<0.0001$ \\
\hline Other & 1.04 & 0.13 & 7.94 & $<0.0001$ \\
\hline ROELag & 23.92 & 14.32 & 1.67 & 0.0965 \\
\hline ROALag & -78.94 & 25.16 & -3.14 & 0.0020 \\
\hline EPSLag & 0.11 & 0.19 & 0.58 & 0.5635 \\
\hline DMining & 3111.50 & 708.16 & 4.39 & $<0.0001$ \\
\hline Dindustrial & 2285.07 & 631.65 & 3.62 & 0.0004 \\
\hline
\end{tabular}

Source: Author's analysis

The model accounts for $46.2 \%$ of the variation in salary $\left(R^{2}=0.462\right)$, and the overall model is significant $\left(F_{9,179}=17.01, p<0.0001\right)$. Lagged ROE, lagged EPS and Age are all not significant, as they have $p$-values greater than .05. However, ROA lagged is significant, as it has a $p$-value less than .05. Salary is negatively correlated to lagged ROA, as it decreases on average by R78 940.00 for each unit increase in ROA $\left(t_{179}=-3.14, p=.0020\right)$.

The Mining and Industrial Sectors have significantly higher salaries than the Financial Services Sector (Mining Sector: $t_{179}=4.39, p<.0001$; Industrial Sector: $t_{179}=3.62, p=.0004$ ). On average the Mining Sector CEOs receive R3 111500.00 more in salary than the Financial Services Sector, and the Industrial Sector CEOs receive an average of R2 285070.00 more in salary than the Financial Services Sector.

Service, Bonus and 'Other' remuneration are all positively correlated to salary. For every 1 year of service, salary increases on average by R177 $670.00\left(t_{179}=3.30, p=.0012\right)$. For every R1 000.00 increase in bonus, salary increases on average by $\mathrm{R} 166.00\left(t_{179}=4.33, p<.0001\right)$. For every $R 1000.00$ increase in 'Other' remuneration, salary increases on average by R1 $041.00\left(t_{179}=7.94\right.$, $p<.0001)$.

There was no significant autocorrelation present (Durbin-Watson test: $d=2.01,4-d=1.99, d_{L}=$ $\left.1.665, d_{U}=1.874, p>.05\right)$. There was also no evidence of heteroscedasticity of the disturbance variances (Breusch-Pagan Godfrey test: $\left.n R^{2}=13.23, \chi_{5}^{2}(0.01)=15.09, p>.02\right)$, nor was there evidence of multicollinearity among the regressors (all pair-wise correlation coefficients < 0.78 ). The disturbances, however, failed the test of normality (Kolmogorov-Smirnov test: $K-S=$ $0.1211, n=189 ; p<.01)$. 


\subsection{Bonus as dependent variable}

\section{TABLE 3: Descriptive statistics for bonus}

All figures except for $n$ are given in thousands, and refer to South African Rands.

\begin{tabular}{|c|c|c|c|c|c|c|c|}
\hline Sector & year & $n$ & Mean & Std. Dev. & Std. Err. & lower $95 \%$ & upper $95 \%$ \\
\hline & 2006 & 36 & 5137.94 & 5173.46 & 862.24 & 3387.50 & 6888.39 \\
\hline & 2007 & 37 & 5805.12 & 7962.18 & 1308.97 & 3150.40 & 8459.85 \\
\hline & 2008 & 39 & 6033.58 & 8157.61 & 1306.26 & 3389.19 & 8677.97 \\
\hline & 2009 & 39 & 4975.39 & 4408.06 & 705.86 & 3546.46 & 6404.32 \\
\hline & 2010 & 39 & 6200.62 & 6559.29 & 1050.33 & 4074.35 & 8326.90 \\
\hline Financial & 2006 & 10 & 8136.49 & 6054.35 & 1914.55 & 3805.47 & 12467.52 \\
\hline Financial & 2007 & 11 & 11683.49 & 10834.55 & 3266.74 & 4404.74 & 18962.24 \\
\hline Financial & 2008 & 12 & 8835.24 & 11441.86 & 3302.98 & 1565.42 & 16105.05 \\
\hline Financial & 2009 & 12 & 5468.26 & 5110.39 & 1475.24 & 2221.27 & 8715.25 \\
\hline Financial & 2010 & 12 & 5657.99 & 4424.41 & 1277.22 & 2846.86 & 8469.13 \\
\hline Mining & 2006 & 12 & 3829.82 & 3932.94 & 1135.34 & 1330.94 & 6328.69 \\
\hline Mining & 2007 & 12 & 2685.32 & 3502.48 & 1011.08 & 459.95 & 4910.69 \\
\hline Mining & 2008 & 12 & 3650.91 & 4081.05 & 1178.10 & 1057.93 & 6243.89 \\
\hline Mining & 2009 & 12 & 4428.65 & 3754.99 & 1083.97 & 2042.84 & 6814.46 \\
\hline Mining & 2010 & 12 & 5600.94 & 4591.82 & 1325.54 & 2683.43 & 8518.44 \\
\hline Industrial & 2006 & 14 & 4117.37 & 4896.54 & 1308.66 & 1290.20 & 6944.55 \\
\hline Industrial & 2007 & 14 & 3860.52 & 5708.32 & 1525.61 & 564.64 & 7156.41 \\
\hline Industrial & 2008 & 15 & 5698.40 & 7277.57 & 1879.06 & 1668.21 & 9728.59 \\
\hline Industrial & 2009 & 15 & 5018.49 & 4547.15 & 1174.07 & 2500.36 & 7536.62 \\
\hline Industrial & 2010 & 15 & 7114.48 & 9131.12 & 2357.64 & 2057.83 & 12171.12 \\
\hline
\end{tabular}

Source: Author's analysis 
TABLE 4: Econometric Model 2 showing bonus as the dependent variable with lagged ROE, ROA and EPS

\begin{tabular}{|c|c|c|c|c|}
\hline \multirow[t]{2}{*}{$n=189$} & \multicolumn{4}{|c|}{$\begin{array}{l}\text { Regression Summary for Dependent Variable: Bonus } \\
R=0.482, R^{2}=0.232 \text {, Adjusted } R^{2}=0.194 \\
F(9,179)=6.02, p<.0001\end{array}$} \\
\hline & $B$ & Std.Err.ofb & $t(179)$ & $p$-value \\
\hline Intercept & -10466.39 & 5342.03 & 1.96 & 0.0516 \\
\hline Age & 340.15 & 108.12 & 3.15 & 0.0019 \\
\hline Service & 313.78 & 100.09 & -3.14 & 0.0020 \\
\hline Salary & 0.57 & 0.13 & 4.33 & $<0.0001$ \\
\hline Other & 0.13 & 0.28 & 0.45 & 0.6567 \\
\hline ROELag & -9.21 & 26.73 & -0.34 & 0.7307 \\
\hline ROALag & 58.61 & 47.69 & 1.23 & 0.2207 \\
\hline EPSLag & -0.44 & 0.35 & -1.23 & 0.2193 \\
\hline \multirow[t]{2}{*}{$n=189$} & \multicolumn{4}{|c|}{$\begin{array}{l}\text { Regression Summary for Dependent Variable: Bonus } \\
R=0.482, R^{2}=0.232 \text {, Adjusted } R^{2}=0.194 \\
F(9,179)=6.02, p<.0001\end{array}$} \\
\hline & B & Std.Err.ofb & $t(179)$ & $p$-value \\
\hline DMining & -6213.05 & 1300.83 & -4.78 & $<0.0001$ \\
\hline Dindustrial & -3511.18 & 1183.80 & -2.97 & 0.0034 \\
\hline
\end{tabular}

Source: Author's analysis

The model accounts for $23.2 \%$ of the variation in Bonus $\left(R^{2}=0.232\right)$, and the overall model is significant $\left(F_{9,179}=6.02, p<.0001\right)$. Lagged ROE, ROA, EPS and 'Other' remuneration are not significant, as they all have $p$-values greater than .05 .

The Mining and Industrial Sectors have significantly lower bonuses than the Financial Sector (Mining Sector: $t_{179}=-4.78, p<.0001$; Industrial Sector: $t_{179}=-2.97, p=.0034$ ). The Financial Services Sector receives higher average bonuses than both the Mining Sector CEOs (R6 213050.00 more) and the Industrial Sector CEOs (R3 511180.00 more).

Age and Salary are both positively correlated to bonus. If age increases by 1 year, bonus increases on average by R340 $150.00\left(t_{179}=3.15, p=.0019\right)$, while for every R1 000.00 increase in salary, bonus increases on average by $\mathrm{R} 570.00\left(t_{179}=4.33, p<.0001\right)$. Service is negatively correlated to bonus: for every $l$ year of service, bonus decreases on average by R313 $780.00\left(t_{179}\right.$ $=-3.14, p=.0020)$.

There was no significant autocorrelation present (Durbin-Watson test: $d=2.05,4-d=1.99, d_{L}=$ $\left.1.665, d_{U}=1.874, p>.05\right)$. There was also no evidence of heteroscedasticity of the disturbance variances (Breusch-Pagan Godfrey test: $\left.n R^{2}=3.99, \chi_{5}^{2}(0.01)=15.09, p>.55\right)$ nor was there evidence of multicollinearity among the regressors (all pair-wise correlation coefficients < 0.78 ). The disturbances, however, failed the test of normality (Kolmogorov-Smirnov test: $K-S=$ $0.1324, n=189 ; p<.01)$. 


\section{3 'Other' remuneration as dependent variable}

\section{TABLE 5: Descriptive statistics for 'other' remuneration}

All figures except for $n$ are given in thousands, and refer to South African Rands.

\begin{tabular}{|c|c|c|c|c|c|c|c|}
\hline Sector & year & $n$ & Mean & Std. Dev. & Std. Err. & lower $95 \%$ & upper $95 \%$ \\
\hline & 2006 & 36 & 947.43 & 1067.55 & 177.93 & 586.23 & 1308.64 \\
\hline & 2007 & 37 & 1574.96 & 2791.07 & 458.85 & 644.37 & 2505.55 \\
\hline & 2008 & 39 & 1476.52 & 2328.55 & 372.87 & 721.70 & 2231.35 \\
\hline & 2009 & 39 & 1370.74 & 1539.31 & 246.49 & 871.76 & 1869.73 \\
\hline & 2010 & 39 & 1339.79 & 1410.26 & 225.82 & 882.64 & 1796.94 \\
\hline Financial & 2006 & 10 & 845.79 & 1146.09 & 362.42 & 25.93 & 1665.65 \\
\hline Financial & 2007 & 11 & 976.31 & 1376.25 & 414.95 & 51.74 & 1900.89 \\
\hline Financial & 2008 & 12 & 764.12 & 877.26 & 253.24 & 206.74 & 1321.51 \\
\hline Financial & 2009 & 12 & 829.12 & 989.71 & 285.71 & 200.29 & 1457.95 \\
\hline Financial & 2010 & 12 & 961.17 & 991.70 & 286.28 & 331.08 & 1591.27 \\
\hline Mining & 2006 & 12 & 911.36 & 1017.09 & 293.61 & 265.13 & 1557.58 \\
\hline Mining & 2007 & 12 & 2278.00 & 4509.47 & 1301.77 & -587.18 & 5143.18 \\
\hline Mining & 2008 & 12 & 2114.83 & 3167.60 & 914.41 & 102.24 & 4127.43 \\
\hline Mining & 2009 & 12 & 1659.15 & 1758.07 & 507.51 & 542.12 & 2776.17 \\
\hline Mining & 2010 & 12 & 1170.95 & 1171.08 & 338.06 & 426.89 & 1915.02 \\
\hline Industrial & 2006 & 14 & 1050.96 & 1123.82 & 300.35 & 402.08 & 1699.84 \\
\hline Industrial & 2007 & 14 & 1442.71 & 1459.62 & 390.10 & 599.95 & 2285.47 \\
\hline Industrial & 2008 & 15 & 1535.80 & 2332.58 & 602.27 & 244.06 & 2827.54 \\
\hline Industrial & 2009 & 15 & 1573.32 & 1693.10 & 437.16 & 635.71 & 2510.92 \\
\hline Industrial & 2010 & 15 & 1777.75 & 1787.50 & 461.53 & 787.87 & 2767.64 \\
\hline
\end{tabular}

Source: Author's analysis 
TABLE 6: Econometric Model 3 showing 'other' remuneration as the dependent variable with lagged ROE, ROA and EPS

\begin{tabular}{|c|c|c|c|c|}
\hline \multirow[t]{2}{*}{$n=189$} & \multicolumn{3}{|c|}{$\begin{array}{l}\text { Regression Summary for Dependent Variable: Other } \\
R=0.612, R^{2}=0.375 \text {, Adjusted } R^{2}=0.343 \\
F(9,179)=11.91, p<.0001\end{array}$} & \multirow[b]{2}{*}{$p$-value } \\
\hline & $B$ & Std.Err.ofb & $t(179)$ & \\
\hline Intercept & -2287.81 & 1417.81 & -1.61 & 0.1084 \\
\hline Age & 42.77 & 29.20 & 1.46 & 0.1448 \\
\hline Service & -20.91 & 27.15 & -0.77 & 0.4421 \\
\hline Salary & 0.25 & 0.03 & 7.94 & $<0.0001$ \\
\hline Bonus & 0.01 & 0.02 & 0.45 & 0.6566 \\
\hline ROELag & -17.29 & 6.95 & -2.49 & 0.0138 \\
\hline ROALag & 23.48 & 12.54 & 1.87 & 0.0629 \\
\hline EPSLag & -0.15 & 0.09 & 1.65 & 0.1017 \\
\hline DMining & 46.62 & 365.33 & 0.13 & 0.8986 \\
\hline Dindustrial & -112.34 & 320.62 & -0.35 & 0.7265 \\
\hline
\end{tabular}

Source: Author's analysis

The model accounts for $37.5 \%$ of the variation in 'Other' remuneration $\left(R^{2}=0.375\right)$, and the overall model is significant $\left(F_{9,179}=11.91, p<.0001\right)$. Lagged ROA, EPS, Bonus, Age and Service are all not significant as their $p$-values are greater than .05 . The Mining and Industrial sectors are not significant ( $p$-values greater than .05). The ROE lag is significant ( $p$-value less than .05 ), as 'Other' remuneration decreases on average by R17 290.00 for each unit increase in ROE $\left(t_{179}=-2.49, p=.0138\right)$. Salary is positively correlated to 'Other' remuneration. For every $\mathrm{R} 1000.00$ increase in salary, 'Other' remuneration increases on average by $\mathrm{R} 250.00\left(t_{179}=7.94\right.$, $p<.0001)$.

There was no significant autocorrelation present (Durbin-Watson test: $d=2.10,4-d=1.90, d_{L}=$ $\left.1.665, d_{U}=1.874, p>.05\right)$. There was also no evidence of heteroscedasticity of the disturbance variances (Breusch-Pagan Godfrey test: $n R^{2}=15.12, \chi_{5}^{2}(0.01)=15.09, p>.01$ ), nor was there evidence of multicollinearity among the regressors (all pair-wise correlation coefficients < 0.78 ). The disturbances, however, failed the test of normality (Kolmogorov-Smirnov test: $K-S=$ $0.2016, n=189 ; p<.01)$.

\section{THE EFFECT OF COMPANY PERFORMANCE ON CEO COMPENSATION}

This section shows the effect of a change in company performance on CEO compensation. The layout of this section is the same as that of previous section: for each variable of company performance a table of descriptive statistics, a graph showing the average amounts of that variable for each of the three sectors and an econometric model is presented, along with results and finally the findings of the diagnostic tests of the assumptions of the linear model. 


\subsection{ROE as dependent variable}

\section{TABLE 7: Descriptive statistics for ROE}

All figures except for $n$ are given as a percentage.

\begin{tabular}{|c|c|c|c|c|c|c|c|}
\hline Sector & year & $n$ & Mean & Std. Dev. & Std. Err. & lower $95 \%$ & upper $95 \%$ \\
\hline & 2005 & 38 & 22.78 & 12.85 & 2.08 & 18.56 & 27.00 \\
\hline & 2006 & 39 & 35.01 & 46.45 & 7.44 & 19.95 & 50.06 \\
\hline & 2007 & 39 & 25.93 & 19.76 & 3.16 & 19.53 & 32.34 \\
\hline & 2008 & 40 & 19.18 & 34.98 & 5.53 & 7.99 & 30.36 \\
\hline & 2009 & 40 & 19.66 & 24.05 & 3.80 & 11.97 & 27.35 \\
\hline Financial & 2005 & 11 & 20.45 & 7.65 & 2.31 & 15.31 & 25.59 \\
\hline Financial & 2006 & 11 & 24.17 & 7.82 & 2.36 & 18.91 & 29.42 \\
\hline Financial & 2007 & 11 & 24.44 & 8.43 & 2.54 & 18.78 & 30.11 \\
\hline Financial & 2008 & 12 & 17.43 & 5.78 & 1.67 & 13.76 & 21.11 \\
\hline Financial & 2009 & 12 & 12.82 & 7.38 & 2.13 & 8.13 & 17.51 \\
\hline Mining & 2005 & 12 & 21.35 & 17.49 & 5.05 & 10.24 & 32.46 \\
\hline Mining & 2006 & 12 & 55.66 & 80.53 & 23.25 & 4.49 & 106.83 \\
\hline Mining & 2007 & 12 & 29.16 & 30.81 & 8.89 & 9.59 & 48.74 \\
\hline Mining & 2008 & 12 & 25.12 & 42.46 & 12.26 & -1.85 & 52.10 \\
\hline Mining & 2009 & 12 & 16.30 & 27.14 & 7.84 & -0.94 & 33.55 \\
\hline Industrial & 2005 & 15 & 25.63 & 11.82 & 3.05 & 19.09 & 32.18 \\
\hline Industrial & 2006 & 16 & 26.97 & 13.14 & 3.28 & 19.97 & 33.97 \\
\hline Industrial & 2007 & 16 & 24.53 & 15.28 & 3.82 & 16.39 & 32.67 \\
\hline Industrial & 2008 & 16 & 16.03 & 42.36 & 10.59 & -6.55 & 38.60 \\
\hline Industrial & 2009 & 16 & 27.31 & 28.54 & 7.14 & 12.10 & 42.52 \\
\hline
\end{tabular}

Source: Author's analysis 
TABLE 8: Econometric Model 4 showing ROE lagged as the dependent variable

\begin{tabular}{|c|c|c|c|c|}
\hline \multirow[t]{2}{*}{$n=189$} & \multicolumn{3}{|c|}{$\begin{array}{l}\text { Regression Summary for Dependent Variable: ROELag } \\
\mathrm{R}=0.198, \mathrm{R}^{2}=0.039 \text {, Adjusted } \mathrm{R}^{2}=0.002 \\
F(7,181)=1.05, p=.3976\end{array}$} & \multirow[b]{2}{*}{$p$-value } \\
\hline & B & Std.Err. of $b$ & $t(181)$ & \\
\hline Intercept & 49.98 & 27.25 & 1.83 & 0.0683 \\
\hline Age & -0.61 & 0.56 & -1.09 & 0.2775 \\
\hline Service & 0.55 & 0.51 & 1.09 & 0.2772 \\
\hline Salary & -0.0003 & 0.0007 & -0.54 & 0.5875 \\
\hline Bonus & 0.00001 & 0.0004 & 0.02 & 0.9821 \\
\hline Other & -0.0012 & 0.0014 & -0.83 & 0.4070 \\
\hline DMining & 13.61 & 6.43 & 2.12 & 0.0357 \\
\hline DIndustrial & 5.92 & 5.84 & 1.01 & 0.3115 \\
\hline
\end{tabular}

Source: Author's analysis

The model accounts for only $3.9 \%$ of the variation in ROE $\left(R^{2}=0.039\right)$, and the overall model is not significant $\left(F_{7,181}=1.05, p=.3976\right)$. Salary, Bonus, Other, Service, Age and Industrial Sector are not significant, as all of their $p$-values are greater than .05 .

The Mining Sector has significantly higher ROEs than the Financial Services Sector (Mining Sector: $\left.t_{181}=2.12, p=.0357\right)$. On average the Mining sector ROEs are $13.61 \%$ higher than the Financial Services sector.

There was no significant autocorrelation present (Durbin-Watson test: $d=1.90, d_{L}=1.686, d_{U}=$ $1.852, p>.05)$. There was also no evidence of heteroscedasticity of the disturbance variances (Breusch-Pagan Godfrey test: $n R^{2}=2.08, \chi_{3}^{2}(0.01)=11.34, p>.61$ ), nor was there evidence of multicollinearity among the regressors (all pair-wise correlation coefficients < .58). The disturbances, however, failed the test of normality (Kolmogorov-Smirnov test: $K-S=0.2099$, $n=189 ; p<.01)$.

\subsection{ROA as dependent variable}

\section{TABLE 9: Descriptive statistics for ROA}

All figures except for $n$ are given as a percentage.

\begin{tabular}{cccrrrrr}
\hline Sector & Year & \multicolumn{1}{c}{$n$} & \multicolumn{1}{c}{ Mean } & Std. Dev. & Std. Err. & lower 95\% & upper 95\% \\
\hline \multirow{5}{*}{2005} & 38 & 13.41 & 9.44 & 1.53 & 10.31 & 16.51 \\
& 2006 & 39 & 18.95 & 22.41 & 3.59 & 11.68 & 26.21 \\
& 2007 & 39 & 16.07 & 13.49 & 2.16 & 11.69 & 20.44 \\
& 2008 & 40 & 15.74 & 18.29 & 2.89 & 9.89 & 21.59 \\
& 2009 & 40 & 12.49 & 14.84 & 2.35 & 7.75 & 17.24 \\
\hline Financial & 2005 & 11 & 7.60 & 8.88 & 2.68 & 1.64 & 13.57
\end{tabular}




\begin{tabular}{lrlrrrrr}
\hline \multicolumn{1}{c}{ Sector } & Year & $n$ & \multicolumn{1}{c}{ Mean } & Std. Dev. & Std. Err. & lower 95\% & upper 95\% \\
\hline Financial & 2006 & 11 & 7.59 & 9.05 & 2.73 & 1.51 & 13.67 \\
Financial & 2007 & 11 & 7.05 & 8.26 & 2.49 & 1.50 & 12.60 \\
\hline Financial & 2008 & 12 & 7.41 & 9.77 & 2.82 & 1.20 & 13.61 \\
Financial & 2009 & 12 & 4.78 & 5.45 & 1.57 & 1.32 & 8.24 \\
\hline Mining & 2005 & 12 & 14.14 & 8.59 & 2.48 & 8.69 & 19.60 \\
Mining & 2006 & 12 & 30.96 & 35.04 & 10.11 & 8.70 & 53.22 \\
\hline Mining & 2007 & 12 & 22.66 & 15.93 & 4.60 & 12.54 & 32.79 \\
Mining & 2008 & 12 & 22.42 & 24.86 & 7.18 & 6.62 & 38.21 \\
\hline Mining & 2009 & 12 & 12.53 & 20.01 & 5.78 & -0.19 & 25.24 \\
Industrial & 2005 & 15 & 17.08 & 8.93 & 2.30 & 12.14 & 22.03 \\
\hline Industrial & 2006 & 16 & 17.75 & 10.29 & 2.57 & 12.26 & 23.23 \\
Industrial & 2007 & 16 & 17.32 & 11.54 & 2.88 & 11.17 & 23.47 \\
Industrial & 2008 & 16 & 16.98 & 15.92 & 3.98 & 8.50 & 25.46 \\
\hline Industrial & 2009 & 16 & 18.25 & 13.20 & 3.30 & 11.22 & 25.29 \\
\hline Source: $A u t h 0 r ' s a n d y s i s$ & & & & & \\
\hline
\end{tabular}

Source: Author's analysis

TABLE 10: Econometric Model 5 showing ROA lagged as the dependent variable

\begin{tabular}{|c|c|c|c|c|}
\hline \multirow[t]{2}{*}{$n=189$} & \multicolumn{3}{|c|}{$\begin{array}{l}\text { Regression Summary for Dependent Variable: ROALag } \\
\mathrm{R}=0.420, \mathrm{R}^{2}=0.176 \text {, Adjusted } \mathrm{R}^{2}=0.144 \\
F(7,181)=5.53, p<.0001\end{array}$} & \multirow[b]{2}{*}{$p$-value } \\
\hline & $B$ & Std.Err. of $b$ & $t(181)$ & \\
\hline Intercept & 27.84 & 13.56 & 2.05 & 0.0415 \\
\hline Age & -0.45 & 0.28 & -1.61 & 0.1096 \\
\hline Service & 0.64 & 0.25 & 2.55 & 0.0117 \\
\hline Salary & -0.00082 & 0.0003 & -2.35 & 0.0200 \\
\hline Bonus & 0.00015 & 0.0002 & 0.80 & 0.4267 \\
\hline Other & 0.00031 & 0.0007 & 0.42 & 0.6713 \\
\hline DMining & 17.72 & 3.20 & 5.53 & $<0.0001$ \\
\hline DIndustrial & 11.92 & 2.91 & 4.10 & 0.0001 \\
\hline
\end{tabular}

Source: Author's analysis

The model accounts for $17.6 \%$ of the variation in ROA $\left(R^{2}=0.176\right)$, and the overall model is significant $\left(F_{7,181}=5.53, p<.0001\right)$. Bonus, 'Other' remuneration and Age are all not significant, as their $p$-values are greater than .05 .

The Mining and Industrial Sectors have significantly higher ROAs than the Financial Services Sector (Mining Sector: $t_{181}=5.53, p<.0001$; Industrial Sector: $t_{181}=4.10, p<.0001$ ). On average the Mining Sector ROAs are 17.72 percentage points higher than the Financial Services Sector, 
and the Industrial Sector ROAs are 11.92 percentage points higher than the Financial Services Sector.

Service is significant ( $p$-value of less than .05), as ROA increases on average by 0.64 percentage points for each additional year of service $\left(t_{181}=2.55, p=.0117\right)$. Salary, however, is negatively correlated to ROA, as for every R1 000.00 increase in salary R0A decreases on average by 0.00082 percentage points $\left(t_{181}=-2.35, p=.0200\right)$.

There was no significant autocorrelation present (Durbin-Watson test: $d=2.03,4-d=1.97, d_{L}=$ $\left.1.686, d_{U}=1.852, p>.05\right)$. There was also no evidence of heteroscedasticity of the disturbance variances (Breusch-Pagan Godfrey test: $n R^{2}=1.85, \chi_{3}^{2}(0.01)=11.34, p>.60$ ), nor was there evidence of multicollinearity among the regressors (all pair-wise correlation coefficients < 0.58 ). The disturbances, however, failed the test of normality (Kolmogorov-Smirnov test: $K-S=$ $0.1297, n=189 ; p<.01)$.

\subsection{EPS as dependent variable}

\section{TABLE 11: Descriptive statistics for EPS}

All figures except for $n$ are given in South African cents.

\begin{tabular}{lrrrrrrr}
\hline \multicolumn{1}{c}{ Sector } & Year & \multicolumn{1}{c}{$n$} & \multicolumn{1}{c}{ Mean } & Std. Dev. & Std. Err. & lower 95\% & upper 95\% \\
\hline & 2005 & 38 & 618.77 & 599.02 & 97.17 & 421.88 & 815.66 \\
& 2006 & 39 & 1070.50 & 1487.15 & 238.13 & 588.42 & 1552.58 \\
& 2007 & 39 & 939.60 & 1127.99 & 180.62 & 573.94 & 1305.25 \\
& 2008 & 40 & 736.05 & 2400.71 & 379.59 & -31.73 & 1503.84 \\
& 2009 & 40 & 819.80 & 1614.20 & 255.23 & 303.55 & 1336.04 \\
\hline Financial & 2005 & 11 & 454.18 & 317.75 & 95.81 & 240.72 & 667.65 \\
\hline Financial & 2006 & 11 & 603.27 & 411.41 & 124.04 & 326.89 & 879.66 \\
\hline Financial & 2007 & 11 & 729.62 & 500.00 & 150.76 & 393.71 & 1065.53 \\
\hline Financial & 2008 & 12 & 679.55 & 533.67 & 154.06 & 340.47 & 1018.62 \\
\hline Financial & 2009 & 12 & 455.61 & 412.05 & 118.95 & 193.80 & 717.41 \\
\hline Mining & 2005 & 12 & 699.51 & 817.45 & 235.98 & 180.13 & 1218.89 \\
\hline Mining & 2006 & 12 & 1560.68 & 2086.15 & 602.22 & 235.21 & 2886.15 \\
\hline Mining & 2007 & 12 & 1346.94 & 1751.10 & 505.50 & 234.34 & 2459.54 \\
\hline Mining & 2008 & 12 & 1449.99 & 2652.13 & 765.60 & -235.09 & 3135.07 \\
\hline Mining & 2009 & 12 & 633.52 & 1034.50 & 298.63 & -23.77 & 1290.81 \\
\hline Industrial & 2005 & 15 & 674.88 & 566.49 & 146.27 & 361.17 & 988.59 \\
\hline Industrial & 2006 & 16 & 1024.08 & 1394.21 & 348.55 & 281.16 & 1767.01 \\
\hline Industrial & 2007 & 16 & 778.44 & 784.34 & 196.09 & 360.50 & 1196.39 \\
\hline Industrial & 2008 & 16 & 242.97 & 2991.37 & 747.84 & -1351.01 & 1836.96 \\
\hline Industrial & 2009 & 16 & 1232.64 & 2355.78 & 588.94 & -22.66 & 2487.95 \\
\hline Source: Author's & 12 & & & & & \\
\hline
\end{tabular}

Source: Author's analysis 
Bradley

TABLE 12: Econometric Model 5 showing ROA lagged as the dependent variable

\begin{tabular}{|c|c|c|c|c|}
\hline \multirow[t]{2}{*}{$n=189$} & \multicolumn{4}{|c|}{$\begin{array}{l}\text { Regression Summary for Dependent Variable: EPSLag } \\
R=0.227, R^{2}=0.051 \text {, Adjusted } R^{2}=0.015 \\
F(7,181)=1.40, p=.2079\end{array}$} \\
\hline & $B$ & Std.Err. of $b$ & $t(181)$ & $p$-value \\
\hline Intercept & -1564.69 & 1393.94 & -1.12 & 0.2631 \\
\hline Age & 50.87 & 28.70 & 1.77 & 0.0780 \\
\hline Service & -56.83 & 25.94 & -2.19 & 0.0297 \\
\hline Salary & 0.01 & 0.04 & 0.25 & 0.8037 \\
\hline Bonus & -0.02 & 0.02 & -1.01 & 0.3140 \\
\hline Other & 0.05 & 0.07 & 0.73 & 0.4670 \\
\hline DMining & 196.57 & 329.15 & 0.60 & 0.5511 \\
\hline DIndustrial & 258.30 & 298.61 & 0.86 & 0.3882 \\
\hline
\end{tabular}

Source: Author's analysis

The model accounts for only $5.1 \%$ of the variation in EPS $\left(R^{2}=0.051\right)$, and the overall model is not significant $\left(F_{7,181}=1.40, p=.2079\right)$. Salary, Bonus, 'Other' remuneration and Age are all not significant ( $p$-values greater than .05). The Mining and Industrial Sectors are also not significant ( $p$-values greater than .05). Service is negatively correlated to EPS (for every 1 year of service, EPS decreases on average by 56.83 cents $\left(t_{181}=-2.19, p=.0297\right)$ ).

There was no significant autocorrelation present (Durbin-Watson test: $d=2.14,4-d=1.86, d_{L}=$ $\left.1.686, d_{U}=1.852, p>.05\right)$. There was also no evidence of heteroscedasticity of the disturbance variances (Breusch-Pagan Godfrey test: $n R^{2}=1.81, \chi_{3}^{2}(0.01)=11.34, p>.61$ ), nor was there evidence of multicollinearity among the regressors (all pair-wise correlation coefficients < 0.58 ). The disturbances, however, failed the test of normality (Kolmogorov-Smirnov test: $K-S=$ $0.1947, n=189 ; p<.01)$.

\subsection{Correlation matrix table}

The following correlation matrix table indicates only the linear relationship between two variables. Unlike the econometric models, it does not take any other predictor variables into account. The probability value $(p)$ is the probability that the $t$-distribution has a value greater than or equal to the absolute sample value of the test statistics (Grunditz \& Lindqvist, 2003). A probability value which is less than the level of significance will result in the null hypothesis being rejected. Grunditz and Lindqvist (2003:36) use .05 as the level of significance, noting that the 'majority of the previous research studies have selected a significance level of .05.' Performance measures are lagged as these are more likely to be correlated to C $E 0$ remuneration, and probability values of less than .05 are shown in bold. 
TABLE 13: A correlation matrix using lagged performance measures

\begin{tabular}{lrrrrrrrr}
\hline \multirow{2}{*}{ Variable } & \multicolumn{1}{c}{ Age } & Service & Salary & Bonus & Other & ROELag & ROALag & EPSLag \\
\hline Age & 1.0000 & .5862 & .2139 & .1869 & .2108 & -.0749 & -.0306 & .0393 \\
& $p=---$ & $p=.000$ & $p=.003$ & $p=.010$ & $p=.004$ & $p=.306$ & $p=.676$ & $p=.591$ \\
Service & .5862 & 1.0000 & .2085 & .0374 & .0964 & -.0149 & .0549 & -.1192 \\
& $p=.000$ & $p=---$ & $p=.004$ & $p=.609$ & $p=.187$ & $p=.839$ & $p=.453$ & $p=.102$ \\
Salary & .2139 & .2085 & 1.0000 & .3005 & .5764 & -.0644 & -.0588 & .0408 \\
& $p=.003$ & $p=.004$ & $p=---$ & $p=.000$ & $p=.000$ & $p=.378$ & $p=.422$ & $p=.577$ \\
Bonus & .1869 & .0374 & .3005 & 1.0000 & .2079 & -.0821 & -.1065 & -.0515 \\
& $p=.010$ & $p=.609$ & $p=.000$ & $p=---$ & $p=.004$ & $p=.261$ & $p=.145$ & $p=.481$ \\
Other & .2108 & .0964 & .5764 & .2079 & 1.0000 & -.0887 & -.0041 & .0862 \\
& $p=.004$ & $p=.187$ & $p=.000$ & $p=.004$ & $p=---$ & $p=.225$ & $p=.956$ & $p=.238$ \\
ROELag & -.0749 & -.0149 & -.0644 & -.0821 & -.0887 & 1.0000 & .7815 & .5892 \\
& $p=.306$ & $p=.839$ & $p=.378$ & $p=.261$ & $p=.225$ & $p=---$ & $p=.000$ & $p=.000$
\end{tabular}

Source: Author's analysis

As can be seen in the above table, when predictor variables are not taken into account, no correlations between $C \varepsilon 0$ remuneration and lagged performance measures exist. These findings can be considered reasonable, as they are similar to the findings of various prior studies done on this topic. There are, however, correlations between lagged company performance variables. This is to be expected, as if a C£O receives a higher salary it is understandable that the bonus and 'other' remuneration levels would also increase. Correlations also exist between the variables within CEO remuneration. This is to be expected, as the company performance variables used are similar in nature, with the result that a high level of correlation between the variables is to be expected.

It is interesting to note that the age of the $\subset \varepsilon 0$, as well as years of service, is correlated to $\subset \varepsilon 0$ remuneration figures but not to company performance figures. This shows that older and more experienced $C \& O$ s can expect an increase in their remuneration package, although it also shows that companies with older or more experienced C\&Os should not expect the performance of the company to increase relative to other companies.

The results indicate that there is no linear relationship between $C \varepsilon 0$ compensation and company performance variables, regardless of which variables are assumed to be the independent variables. This confirms many of the studies analysed in the literature review, and appears to be consistent with findings in other countries. The econometric models did show correlations between certain variables, after taking into account other predictor variables in the model. 


\section{CONCLUSION AND SUGGESTIONS FOR FURTHER RESEARCH}

\subsection{Summary of findings}

The correlation matrix table in TABLE 13 demonstrates that there is no correlation between any of the C\&O compensation variables and any of the lagged company performance variables. This correlation matrix table indicates only the linear relationship between two variables, and does not take any other predictor variables into account.

The econometric models give an indication of the linear relationship between a predictor variable and the response variable after taking into account the other predictor variables in the model.

The findings in terms of the specific aims of the research are as follows:

- no direct correlation between CEO compensation and company performance was found;

- the (hypothetical) relationship is not influenced by the industry in which the company operates;

- variable compensation (for example bonuses) does not affect the performance of the company;

- C\&O compensation is affected by variables such as the age and experience of the C\&O. More details of these findings are presented below.

\subsubsection{Findings related to CEO compensation}

- Salary, bonus and 'other' remuneration are all positively correlated, which is to be expected. Furthermore, salary is positively correlated to years of service. Every year of service of $C \varepsilon 0 \mathrm{~s}$ results in CEOs salaries increasing on average by R177 670.00. This could suggest that as CEOs gain experience, so their value to the company increases, which results in them commanding a higher salary. Alternatively, a more likely reason is that this is simply due to annual increases which are awarded to CEOs to compensate for inflation.

- Bonus is positively correlated to age. For every year by which the CEOs' ages increase, the bonus payable to CEOs increases on average by R340 150.00. The fact that the CEO bonus is not correlated to years of service (see below) suggests that the bonus does not increase over time due to the experience of the C $£ 0$ s. Although unlikely, it is possible that older CEOs can command greater bonuses simply due to their increased rank and status within the firm.

- CEO bonus is negatively correlated to years of service. For every year of service of the CદO, the $C \varepsilon 0$ bonus decreases on average by $R 313780.00$. It is not immediately clear why this would be the case. The financial crisis, which occurred during the years under review and generally resulted in lower profits being recorded by companies, could have affected this statistic. Bonuses, being variable in nature and depending on the performance of the company, would have decreased due to this downturn in the global economy. This can be seen by the descriptive statistics which were presented, which showed the mean bonus dropping from R6.034 million in 2008 to R4.975 million in 2009 (figures rounded to three decimals). 


\subsubsection{Findings related to company performance}

- ROE lagged is negatively correlated to 'Other' payments. For every one percentage point that ROE increases by, 'Other' payments made to the CEOs decrease on average by R17 290. This amount could be too small to merit further analysis, but it could suggest that when a company makes an effort to increase its ROE it does so by eliminating wasteful expenses, including extra payments previously made to the CEOs. Alternatively, it is suggested that this decrease in 'other' remuneration could be a result of companies minimising their expenses due to the financial crisis rather than as a direct result of company performance.

- ROA lagged is negatively correlated to salary. For every R1 000.00 by which salary increases, the ROA decreases on average by 0.00082 percentage points. It is possible that companies that are focused on increasing their ROA figure will cut down on expenses, which could include a decrease in the CEO's salary. Once again the amounts are too small to merit an indepth analysis into possible reasons for this correlation.

- ROA lagged is positively correlated to years of service. For every year of service of the $\subset \varepsilon 0$, the ROA lagged increases by 0.64 percentage points. This would suggest that as CEOs gain experience they are able to add value to the company, resulting in a higher ROA.

- EPS lagged is negatively correlated to years of service. For every year of service of the C\&O, the EPS of the company decreases on average by 56.83 South African Cents. It is not clear why this would be the case, and it is suggested that this decrease in average EPS could be due to the financial crisis during the period of analysis, rather than due to increased years of service of the CहO.

\subsubsection{Findings related to various sectors within the economy}

- The Financial Services Sector receives lower average salaries than the Mining Sector (R3 111500.00 lower) and the Industrial Sector ( 2285070.00 lower). This added remuneration is, however, offset by the fact that the Financial Services Sector receives significantly higher average bonuses than the Mining Sector (R6 213050.00 higher) and the Industrial Sector (R3 511180.00 higher). This could be due to the Financial Services Sector operating in a different environment in which variable remuneration forms a greater part of the remuneration package of CEOs. There could also be a smaller supply of CEOs who can serve in this sector, meaning that higher bonuses are paid by companies to retain their services.

- The Financial Services Sector has a significantly lower average ROE than the Mining Sector (13.61 percentage points lower). The Financial Services Sector also has a significantly lower average ROA than both the Mining Sector (17.72 percentage points lower) and the Industry Sector (11.92 percentage points lower). It is suggested that different markets and operating environments could explain the lower ROE figures.

\subsection{Recommendations and conclusion}

The research conducted did not find a correlation between $C \& 0$ compensation and company performance, suggesting that attempts to align the interests of managers and shareholders through executive pay in South Africa have so far been unsuccessful. This is bad news for investors, as managers interests may not be the same as theirs (which could result in lower 
returns). It is also bad news for policymakers, as executives not motivated to maximise company performance would have a detrimental effect on the efficiency on the South African economy.

Findings would suggest that firms that attempt to use executive pay as a method of mitigating the conflict of interest that exists between managers and shareholders should consider their approach carefully. Companies may either need to change their pay structure (in order to create a correlation between executive pay and performance), or consider alternative means to align the interests of managers and investors. This research would warn against increasing executive pay as a method of attempting to increase company returns.

There is nothing to suggest that it is not possible to link pay to performance in South Africa. However, in order to maximise CEO performance, as well as limit the conflict of interests between managers and shareholders at an entity level, there are a few goals that would need to be met. Firstly, an entity would need to have an agreed-upon and suitable method of measuring performance. Secondly, there should be a clear and understandable link between company performance and executive pay. All contingencies of the pay for performance model would need to be made known to all parties, and a clear understanding of what constitutes good performance would also need to be agreed upon.

Advantages to creating a good pay for performance model would be the alignment of shareholder and management interests, as well as a powerful tool for attracting and retaining talented executives. With executive pay attracting scrutiny all over the world, the opportune time for implementing such a system has never been better.

\subsection{Suggestions for further research}

It is hoped that this study will encourage further research in South Africa. Expanding the study to include more companies would allow for a greater possibility of finding correlations, as would increasing the number of years' data analysed. In addition, the effects that age and experience of the $C £ 0$ have on both company performance and $C £ 0$ remuneration have largely been ignored by researchers until the present. Lastly, the correlations discovered in the present research between the three different sectors used for the purposes of the research could benefit from further analysis.

\section{Acknowledgement}

The author would to thank his supervisors as well as the statistical department at Rhodes University for their input and guidance into this research article. Their expertise, commitment and professionalism displayed throughout the duration of this thesis are highly valued. The author would also like to thank the Remuneration Department of Deloitte Johannesburg for allowing the author to spend a few days in the department experiencing the practical side of executive remuneration. Lastly, the author is grateful to two anonymous reviewers for suggestions which improved the article.

\section{LIST OF REFERENCES}

Baber, W.R., Kang, S.H. \& Kumar, K.R. (1999). The explanatory power of earnings levels vs. earnings changes in the context of executive compensation. The Accounting Review, 74, pp. 459-472.

Bognanno, M. (2010). Executive compensation: A brief review. [Online]. Available: http://ideas.repec.org/p/tem/wpaper/1002.html. (Accessed 20 October 2010) 
Boschen, J.F. \& Smith, K.J. (1995). You Can Pay Me Now and You Can Pay Me Later: The Dynamic Response of Executive Compensation to Firm Performance. Journal of Business, 68(4), pp. 577-608.

Bunting, M., (2009). Financial Reporting in South Africa. Grahamstown: MB Bunting.

Conyon, M., Gregg, P. \& Machin, S. (1995). Taking Care of Business: Executive Compensation in the United Kingdom. Economic Journal, 105(430), pp. 704-714.

Dommisse, J. (2011). Is die vergoeding van die uitvoerende hoofde van die 120 top-maatskappye van die Johannesburgse aandelebeurs (JSE) in verhouding tot hul omset, inkomste of wins voor rente en belasting geregverdig? (Is the remuneration of chief executives of the 120 top-companies on the Johannesburg Stock Exchange (JSE) in relation to their turnover, income or profit before interest and taxes?) Unpublished M.Com mini-thesis. University of Stellenbosch, South Africa.

Doucouliagos, C., Haman, J. \& Askary, S. (2007). Directors Remuneration and Performance in Australian Banking. Corporate Governance: An International Review, 15(6), pp. 1363-1383.

Eriksson, T. \& Lausten, M. (2000). Managerial pay and firm performance, Scandinavian Journal of Management, 16(3), pp. 269-286.

Farmer, M. (2008). Chief Executive Compensation and Company Performance: a weak relationship or measurement weaknesses? Unpublished report for the $17^{\text {th }}$ EDAMBA Summer Academy. England: Faculty of Business and Law, Kingston University.

Girma, S., Thompson, S. \& Wright, P.W. 2007. Corporate governance reforms and executive compensation determination: Evidence from the UK. The Manchester School, 75(1), pp. 65-81.

Gregg, P., Jewell, S. \& Tonks, I. (2005). Executive Pay and Performance in the UK. Centre for Market and Public Organisation, University of Bristol, England. (Working Paper 05/122).

Grunditz, G. \& Lindqvist, J. (2003). CEO compensation and company performance: An empirical study of the situation in Sweden's listed companies. Unpublished M.Com thesis. School of Economics and Commercial Law: Göteborg University

Hagel III, J., Brown, J.S. \& Davison, L. (2010). The Best Way to Measure Company Performance.

[Online] Available: http://blogs.hbr.org/bigshift/2010/03/the-best-way-to-measurecompan.html. (Accessed 16 September 2011)

Hirschberg, J. \& Lye, J. (2001). The interpretation of multiple dummy variable coefficients: an application to industry effects in wage equations. Applied Economic Letters, 8(11), pp. 701-707.

Institute of Directors Southern Africa. (2009). King Report on Governance for South Africa 2009. [Online] Available: http://african.ipapercms.dk/IOD/KINGIII/kingiiireport/. (Accessed 11 August 2011)

Jensen, M.C. \& Murphy, K.J. (1990). Performance Pay and Top-Management Incentives. Journal of Political Economy, 98, pp. 225-264.

Khu Zwayo, W. \& Matomela, D. (2011). Pumps run dry as strikes intensify. [Online] Available: http://www.iol.co.za/motoring/industry-news/pumps-run-dry-as-strikes-intensify1.1098853?ot=inmsa.ArticlePrintPageLayout.ot. (Accessed 19 August 2011]

Kim, W.y. (2010). Market reaction to limiting executive compensation: Evidence from TARP firms. [Online] Available: http://ssrn.com/abstract=1553394. (Accessed 13 May 2011)

Kozan, J. \& Boulanger, C. (2004). Managing the complex relationship between pay and performance. Ivey Business Journal: Canada, 68(5), pp. 1-8. 
Lambert, R.A. \& Larcker, D.F. (1987). An Analysis of the Use of Accounting and Market Measures of Performance in Executive Compensation. Journal of Accounting Research, 25, pp. 85-125.

Levitt, J.A. (2004). Money, Money, Money. [Online]. Available: http://www.cb.wsu.edu/ nwalcott/ finance325/template/readings/Money,\%20Money,\%20Money.pdf. (Accessed 16 September 2011).

Lund, T. (2012). Investec's Koseff leads corporate gravy train. Finweek, 29 March 2012 (pp. 24-25).

Mäkeläinen, દ. (1998). Economic Value Added as a Management Tool. [Online]. Available: http://www.evanomics.com/evastudy/evastudy.shtml. (Accessed 19 September 2011).

Morrissey, J. (2009). More Angry Investors Say, Throw the Boards Out. [Online]. Available: http://www.time.com/time/business/article/0,8599,1925344,00.html. (Accessed 11 May 2010)

Murphy, K. (1999). Executive compensation. Handbook of Labor Economics, 3(2), pp. 2485-2563.

Oberholzer, M. \& Theunissen, M. (2012). Benchmarking of Johannesburg Stock Exchange CEO

Compensation. International Business \& Economics Research Journal, 11(9), pp. 1061-1076.

Ofek, દ. \& Yermack, D. (2000). Taking stock: equity-based compensation and the evolution of managerial ownership. Journal of Finance, 55, pp. 1367-1384.

Otley, D. (2002). Measuring performance: The accounting perspective. Cambridge: Cambridge University Press.

Ozkan, N. (2011). C $\varepsilon 0$ Compensation and Firm Performance: An Empirical Investigation of UK Panel Data. European Financial Management, 17(2), pp. 260-285.

Pandya, A.M. and Rao, V. (1998). Diversification and Firm Performance: An Empirical Evaluation. Journal of Financial and Strategic Decisions, 11(2), pp. 67-81.

Rosen, S. (1992). Contracts and the market for executives. Oxford: Basil Blackwell.

Profile Media (author unknown). (2010). Profile's stock exchange handbook February 2010 - May 2010. Johannesburg: Profile Media.

Sharma, B. \& Smith, A.E. (2001). Firm Performance and Executive Compensation in Australia and Canada. [Online] Available: http://journals.hil.unb.ca/index.php/jcim/article/view/473/793. (Accessed 13 May 2011)

Shaw, K.W. \& Zhang, M.H. (2010). Is CEO Cash Compensation Punished for Poor Firm Performance? The Accounting Review, 85(3), pp. 1065-1093.

Siciliano, G. (2003). Finance for the non-financial manager. Columbus: The McGraw-Hill Companies, Inc.

South Africa Government Online. (2009). Companies Act No.71 (2008). [Online]. Available: http://www.info.gov.za/view/DownloadFileAction?id=98894. (Accessed 18 0ctober 2013)

Swartz, G. and Eitzen, C. (2011). An empirical evaluation of the level and mix of CEO compensation in South Africa. Southern African Accounting Association International Biennial Conference, George, South Africa. Unpublished conference proceedings.

Temkin, S. (2009). King calls for more transparency. Business Day, 2 September 2009 (p. 1).

Theunissen, P. (2010). Is executive remuneration out of control? Bethlehem: Computus.

Van Zyl Smit, J. \& Nel, S. Executive compensation. Accountancy SA. February 2010 (pp. 14-16). 